\title{
Small and medium enterprises in the context of regional development and innovations
}

\author{
Gulnara Ruchkina \\ Financial University under the Government of the Russian Federation \\ Moscow, Russian Federation \\ GFRuchkina@fa.ru \\ Marina Melnichuk \\ Financial University under the Government of the Russian Federation \\ Moscow, Russian Federation \\ mvmelnichuk@gmail.com

\section{Svetlana Frumina} \\ Financial University under the Government of the Russian Federation \\ Moscow, Russian Federation \\ frumina@mail.ru
}

\section{Grzegorz Mentel}

Rzeszow University of Technology,

Poland

gmentel@prz.edu.pl

Abstract. The current state of economic development and innovations' support often brings small and medium enterprises (SMEs) at the forefront of government fiscal policy. Various policy measures targeted at SMEs' support and development necessarily include measures on promotion of innovations within small business. However, despite substantial efforts undertaken by the authorities to increased financial injections into this area, development of innovations by small businesses faces many obstacles. Statistics on the registered small and medium enterprises shows that the sharp rise of entrepreneurship observed in the early 1990s changed for the stagnation towards the end of the decade and sluggish dynamics of the present time. Unfortunately, as practice shows, measures taken so far do not stimulate significant changes in the development of small business. Moreover, differentiation of small businesses between regions is only increasing, as it is manifested through substitution of divergence for convergence. Our paper analyzes the legal framework regulating small business development as well as state of innovations within SMEs so that to identify the main indicators

Received: June, 2017 1st Revision: August, 2017

Accepted: October, 2017

DOI:

$10.14254 / 2071$ $8330.2017 / 10-4 / 20$ 
contributing to sustainable regional economic growth.

Keywords: small and medium enterprises, regional development, innovations, state support, economic growth.

JEL Classification: M13, M21, R38, R58

\section{INTRODUCTION}

Small and medium enterprises (SMEs) constitute an important part in economic development of any given country and contribute considerably to regional economic development by creating new jobs, providing investment opportunities and forming the economic capital and potential required for sustainable economic growth (Janda et al., 2013; Koudelková \& Svobodová, 2014; Belas et al., 2015; Simionescu et al., 2017). Therefore, supporting growth and development of SMEs as well as innovative policies targeted at fostering their growth should belong to the state-level priorities (Abrhám et al., 2015; Barkhatov, 2016; Barkhatov et al., 2016; Varanavicius et al., 2017). The state support is provided in financial, property, information and consulting forms and it provides one of the most important prerequisites for regional development (Brodzicki, 2016; Niño-Amézquita et al., 2017).

Financial support which may be provided in the form of subsidies, budget investments or state and municipal guarantees for obligations of small and medium-sized enterprises and institutions forms the necessary infrastructure for SMEs. The aim of our paper is to analyze the role and the impact of state support for small and medium enterprises in the context of regional economic and innovative development. The paper is structured as follows: Section 2 features the comprehensive literature review, overviewing the experience with SMEs development in various countries, Section 3 provides the problem definition, Section 4 outlines the methodology used in our research. Section 5 describes the link between innovations and small business. Section 6 presents the empirical model measuring the impact of governmental support on the growth and innovations of SMEs. Finally, Section 7 provides both conclusions and implications.

\section{LITERATURE REVIEW}

Small and medium enterprises constitute the main focus in shaping business development policies in the European Union (EU) coming to the forefront of the world economy (Kozubikova et al., 2015; Ehrenberger et al., 2015; Dai et al., 2017; Durguner, 2017; Kotane \& Kuzmina-Merlino, 2017; Kuhn et al., 2017; Strielkowski et al., 2017; Melnichuk, 2017; Viesi et al., 2017; Machová et al., 2016). According to many researchers, by 2020 more than $50 \%$ of all workplaces will be occupied by sole traders and freelancers. This would bring the issues of pracarization of the economy and the creation of the new class, the so-called "precariate" that embeds the changing social security scheme and the working conditions (Cole, 2016).

According to the OECD, nowadays SMEs account for 60 to $70 \%$ of jobs in most OECD countries where Italy and Japan hold a special place as countries with a permanently significant share of microenterprises and small companies in the economy. Moreover, it is SMEs that provide a predominant number of new jobs in countries that have a significant positive experience in the field of employment, primarily the United States and the Netherlands. 
Beginning with 2003, the World Bank Group performs an annual business survey in 189 countries and publishes a Doing Business report analyzing the advantages and disadvantages of SME regulations in each country.

Despite the positive dynamics, the burden of the legal regulation remains a serious obstacle in the work of SMEs, as small companies are not ready to confront problems related to regulatory issues. The information relating to statutory documents must be accessible with minimal costs, and an important role is given to information technologies. It would be appropriate to organize work on the "one-stop shop" principle or create a single service center.

In all OECD countries, there are government programs to support medium and small businesses which account for a quarter of all regulatory documents adopted at the legislative level (Host'ovecký \& Poláčik, 2016). In Germany, Iceland, Japan and New Zealand they amount to a half. In OECD countries, beginning with 1993 , no less than $\$ 3.75$ billion of public funds are allocated to support "start-ups", purchase of equipment, $R \& D$, provision of qualification and consulting services in the form of grants, tax incentives, low interest loans and sureties. More than $50 \%$ of programs are run at the local level, so such coordination is mandatory.

The main task is to reduce the administrative costs. In order to achieve the above goal, state authorities need to eliminate from laws and regulations any uncertainty, equivocation and ambiguity in interpretation of tax regulations; create a clear, understandable and predictable microclimate in the legal and financial spheres.

The SME regulation by the state should be carried on in five areas: financing, business environment, technology, management, sales markets. The primary financing task of the state is to reduce the risk and cost of direct investment, stimulate and encourage the development of the private capital industry. The OECD countries use a variety of SME funding methods, but the United States and Canada have the best practices in this area.

The main effort of the public sector in supporting venture capital and other types of risk funding should be to reduce the risk and cost of direct investment. The government should complement and encourage the development of the private capital industry also by providing opportunities to improve qualifications and skills of those involved in this activity. Governments should develop effective policies to encourage and support the provision of risk capital. Such policies should focus on: development banks; loan securing schemes; tax incentives; innovations; rules that govern investments of insurance companies and pension funds in private capital; granting loans at incentive rates, etc. Indirect measures include support of the market and legal regulation, training, $R \& D$ promotion and privatization.

SMEs in most of the Western countries often face difficulties in obtaining bank loans. In Canada and the United States, it is relatively easy to obtain initial venture capital. Outside North America, raising funds at an early stage is more difficult, therefore it is better to rely on investments at later stages.

The development of the "limited liability partnership" model in combination with favorable changes in the regulatory sphere (in particular, the permission to use pension funds for direct investments) and the tax code enhanced the capital inflow into the US direct investment market (more than $75 \%$ of venture capital is provided through the limited liability partnership, and pension funds cover the bulk of all financial liabilities). Raising direct investment through the limited liability partnership is becoming popular also outside the United States. Nevertheless, it should be noted that in many OECD countries pension funds are not allowed to participate in direct investment.

In Canada and the United States, sales to portfolio investors is the most common entry method, while in Europe the most widely used are sales within the same industry and the purchase of equity in the company as well as the acquisition of a controlling stake. Limited opportunities for market entry through sales to portfolio investors are a serious obstacle to the development of venture capital in Europe. 
For small and medium-sized enterprises, developing second-tier markets and unlisted securities markets are important. Second-tier markets for initial public offering are effective entry tools common in the United States and, to a lesser extent, in Japan. The problems associated with existing entry mechanisms in countries, with the exception of Japan and the United States, have stimulated the development of new parallel markets, particularly in Western Europe (Strielkowski \& Höschle, 2016).

Addressing the taxation issue, it should be particularly stressed that it can become a heavy burden expressly on SMEs. On the other hand, a proper tax reform can boost the development of small businesses. Arguments in favor of rendering support to small businesses imply definite types of such support: supporting companies in dynamically developing sectors of the economy; supporting companies that have difficulties in raising funds, etc.

The tax system can be used to reduce the high costs borne by small businesses in order to comply with the tax law requirements; stimulate the establishment of new small enterprises; ensure the small business continuity in cases where the management passes from the founder of the company to another person.

Conditions for doing business can be systematically and consistently improved based on regular monitoring of newly introduced regulations. The problem of excessive legal regulation of small business enterprises today is particularly acute in the Russian Federation, so the foreign experience in the monitoring of newly introduced regulations can be quite useful. As the analysis shows, these procedures are most efficiently run in Canada, Great Britain and the Netherlands. The active use of information technologies helps to reduce bureaucratic procedures.

Programs aimed at the use of new technologies should ensure quality control, be customer-focused and promote the introduction of innovative management. The best programs are developed in the US and Germany. The actions of the government should aim to remove obstacles in the way of training companies in the best practices in technology and innovation management. The OECD experience shows that propagation of technologies, initiatives and services can be enhanced if the best practices are used at all levels: strategic and program levels as well as the service provision level. A recent OECD report identified a number of trends in technology expansion programs. Technology expansion programs should include measures to ensure the quality of service providers, appropriate training of consultants and the effectiveness of local delivery systems.

Therefore, the analysis of the foreign experience in regulating small and medium-sized enterprises shows that most countries are trying to reduce administrative barriers, facilitate registration procedures, etc.

In order to simplify administrative procedures, we suggest the use of foreign practices best suited for ensuring compliance with the law requirements. In particular, we want to outline initiatives that can establish a balance between the needs of regulators and the interests of SMEs obliged to comply with the law, namely: i) mandatory environmental impact audit to be included in the new legislation on environmental monitoring and control (Federal executive bodies should be obliged to submit draft regulations to federal bodies authorized to carry out environmental oversight); ii) the use of information technologies and the expansion of electronic document flow in communication with federal and municipal authorities to reduce the bureaucratic burden on SMEs.

\section{PROBLEM DEFINITION}

In recent years, the legislation governing the activities of small and medium-sized enterprises has changed significantly having been supplemented by new legal standards both stimulating and limiting their development. In the period of 2013-2014, a large number of laws and regulations were adopted that 
introduced additional restrictions increasing the financial burden on small and medium-sized businesses, in particular:

- the sales tax was introduced;

- the fixed insurance payment for individual entrepreneurs was increased;

- property tax privileges for enterprises that switched to the simplified taxation system and the single tax on imputed income were abolished.

Among positive innovations in the small business regulation, it is worth noticing that federal subjects of the Russian Federation are granted the right to establish the $0 \%$ tax rate for taxpayers who are registered as individual entrepreneurs and have switched to the simplified or patent taxation system (Gorevaya \& Khayrullina, 2015; Nikolaeva \& Pletnev, 2016; Ershova, 2017; Sadykov, 2017). In 2015, the new provisions of the Tax Code expanded the list of activities (from 47 to 63 items) that can be performed using the patent taxation system. The amendments allowed the municipalities to reduce the UTII (unified tax on imputed income) rate from 15 to 7,5\%. Subject to amendments were the tax holidays that were extended to newly registered individual entrepreneurs, etc.

State measures intended to support small business development can assume a number of approaches, Among the most effective ones, the following can be named:

- change in requirements for ranking business entities as small and medium-sized enterprises.

- $\quad$ adapting packages of measures to support small innovative enterprises (Chibir \& Shirko, 2015);

- alleviating the antimonopoly law requirements for small enterprises (Fidrmuc \& Gundacker, 2017);

- simplifying the procedures related to the patent system of taxation;

- expanding the opportunities allowing the access of small and medium-sized businesses to government procurements (Iwasaki et al., 2016; Paiho et al., 2015), etc.

In a number of cases, an emphasis in the small business development is made via ensuring access to financial resources, granting tax benefits and preferences and reducing administrative barriers to the creation of infrastructure components (Spence, 2016). However, certain disparities that require harmonization and ironing out are observed in state programs and functions of individual institutions that implement measures to boost small businesses which will be discussed in the following sections.

\section{STATE SUPPORT OF SMALL BUSINESS}

The system of government measures to support the development of small businesses typically includes a set of measures for improving the institution of small entrepreneurship specified in adopted regional documents. In order to develop proposals for improving state programs aimed at the support of the institution of small entrepreneurship, one has to analyze the regional programs The analysis of the passports for the programs often shows the disparity of indicators reflecting the results of their implementation.

Judging by the generalized information, none of the federal subjects under survey intend to solve problems related to the follow-up and support of young entrepreneurs (individuals under the age of 30). Therefore, it seems reasonable that regional programs be supplemented with provisions aimed at encouragement of young entrepreneurs.

The authors analyzed the goals and tasks of regional government programs for support of small and medium-sized businesses. Our analysis revealed some inaccuracies and incorrect wordings that make it impossible to check whether the stated goals and tasks are achieved: 
1) The analysis of the subprogram developed by the Republic of Dagestan showed the lack of differentiation between goals and tasks. This fact confirms the non-compliance with paragraph 23 of the Guidelines and complicates assessment of its structure. Besides, the document provides 4 target indicators for 18 diverse tasks, which seems insufficient to assess the effectiveness of the activities carried out.

2) The analysis of the Kirov regional program "Development of Entrepreneurship and External Relations" for 2013-2020, revealed the following disparities:

- according to the program "Development of Entrepreneurship and External Relations", the number of small and medium-sized enterprises by 2020 is expected to reach 25100 units while the program "Support and Development of Small and Medium-Sized Businesses" effective until 2016, figures out 23400 units. That is, the expected number of small and medium-sized enterprises in the Kirov region under SME support programs until 2020 is not clear (Frumina, 2016);

- the whole process of solving the tasks and achievement of the planned results is not divided into stages but only a period until 2020 has been established. It means that the state program of the Kirov region does not comply with the provisions of Federal Law No. 172-FZ, namely its Art. 3, which reads: "The state program is an instrument of strategic planning containing a set of planned activities that are interrelated in terms of tasks, deadlines, executors and resources ..." (Frumina, 2016).

3) The lack of scheduling the program by stages and deadlines is also observed in the state program of the Vladimir region "Development of Small and Medium-Sized Businesses in the Vladimir region for 2014-2020.

The omission of performance indices for medium-sized enterprises in the target indicators, with the concentration on only small business entities, suggests the non-conformance of the target indicators to the tasks of the program and the name of the latter. The target indicators of the subprogram contained in the main part do not correspond to those set out in the annex.

Thus, we came to the conclusion that state programs aiming to stimulate the development of the institution of the small and medium business in the Russian Federation need adjustment. The development of small businesses in the Russian Federation is predetermined both by changes in macroeconomic dynamics and infrastructural and political transformations. Therefore, especially in the crisis situation, the small business policy should be closely coordinated with strategic (planning) and program-target documents.

In Russia, the strategic planning has been known since the 1920s. In the mid-twentieth century, in the era of socialism, the mechanism for the formation and implementation of long-term plans was so well developed that it became a benchmark for Western countries.

By now, almost all federal subjects of the Russian Federation have approved their own state programs for promotion of small and medium-sized businesses but they are not everywhere agreed with strategic documents. Moreover, as noted by domestic researchers, there is no mechanism ensuring the interrelationship of state programs implemented at the federal level and state programs of federal subjects in similar issues, whereas the interrelationship between budget revenues and the strategic planning of socio-economic development has never been directly established (Novikov, 2014; Plotnikov \& Leontyev, 2015; Proskurina et al., 2015; Shaykheeva, 2015).

Despite the fact that the state programs are based on the approved legislative and regulatory documents, namely the strategy of socio-economic development of the Russian Federation, sectoral strategic planning documents, etc., the analysis of their contents does not always reveal the continuity in the documents (Yakovlev, 2016). 
Furthermore, there are no documents in the Russian legislation that contain provisions on the need to reflect strategic documents with their target values in state programs. Therefore, it is often impossible to evaluate the extent to which the state programs achieve the goals and key targets of the state policy. The authors came across this problem when analyzing state programs devoted to development of small businesses in federal subjects of the Russian Federation. In this regard, there are all reasons to argue that the majority of state programs need to be updated, particularly in terms of formulating goals and tasks that need to be interrelated not only with each other but also with the development strategy of the relevant industry. This problem can be solved only at the legislative level by harmonization of relevant documents.

\section{INNOVATIONS AND SMALL BUSINESS}

In order to demonstrate how innovations Strategy for the Development of Small and Medium-Sized Businesses in the Russian Federation until 2030 and the RF State Program "Economic Development and Innovative Economy".

As was mentioned above, the Strategy is the basic document for the shaping and implementation of state programs. In other words, state programs should be developed on the basis of the Strategy and they should not be in conflict with the latter but complement it and one another. At the same time, the Strategy and the State Program have only one common index (indicator) among the target indicators - the number of small and medium-sized business entities (including individual entrepreneurs) per 1,000 people. It is important that this indicator has been planned in the Strategy for the period until 2020 in the quantity of 42 units (Table 1).

Table 1

Target indicators for the implementation of the SMEs strategy in the Russian Federation until 2030 (an excerpt)

\begin{tabular}{|l|c|c|c|c|c|c|c|c|c|}
\hline \multicolumn{1}{|c|}{ Index } & $\begin{array}{c}\text { Unit of } \\
\text { measure }\end{array}$ & 2013 & 2014 & 2015 & 2018 & 2020 & 2025 & 2030 \\
\hline $\begin{array}{l}\text { High quality of state regulation } \\
\begin{array}{l}\text { The number of small and } \\
\text { medium-sized units } \\
\text { (including } \\
\text { entrerprises } \\
\text { individual } \\
\text { people }\end{array}\end{array}$ & 38.5 & 38.8 & 39 & 40 & 42 & 44 & 46 \\
\hline
\end{tabular}

Source: Federal State Statistics Service (2017)

At the same time, the same index in the State Program is 52.7 units. The third strategic document containing indices (indicators) for the development of small and medium-sized businesses is the Development Strategy of the National Warranty System for Support of Small and Medium-Sized Businesses for the period until 2020 approved by the Order of the Economic Development Ministry of Russia dated February 19, 2015 (amended as of December 28, 2015) (further the NWS Strategy).

Strange as it may seem, the NWS Strategy contains the values of the same index that are absolutely inconsistent with the previous documents. A similar situation is observed when comparing the index "the share of the average number of the employed (without external part-timers) at micro-, small and mediumsized enterprises and by individual entrepreneurs in the total number of economically active population (\%)". In the NWS Strategy until 2020 its planned value is $27.2 \%$, compared with $28.4 \%$ as specified in the SME Development Strategy. 
Another inconsistency: as a result of the implementation of subprogram 2 to the state program "Economic Development and Innovative Economy", 150.92 thousand jobs will be created in the small and medium-sized business sector by 2020 .

The NWS strategy gives other targets - 116.5 thousand jobs. Hence it appears that the implementation of only the State Program should yield more jobs than in total using all state support tools, including the provision of state guarantees.

Continuing the analysis of strategic documents, the authors considered SME development programs implemented in regions. The results of the analysis are set out in Table 4.

Table 2

Indicators of state SME development programs implemented in federal subjects of the Russian Federation

\begin{tabular}{|l|c|c|c|c|c|}
\hline \multirow{2}{*}{ Index/federal subject } & \multicolumn{5}{|c|}{ New jobs } \\
\cline { 2 - 6 } & $\mathbf{2 0 1 6}$ & $\mathbf{2 0 1 7}$ & $\mathbf{2 0 1 8}$ & $\mathbf{2 0 1 9}$ & $\mathbf{2 0 2 0}$ \\
\hline State Program & 710.0 & 710.0 & 710.0 & 710.0 & 710.0 \\
\hline Krasnodar Territory & 680.0 & 710.0 & 710.0 & 710.0 & 710.0 \\
\hline State Program & 570.0 & 570.0 & 570.0 & 570.0 & 570.0 \\
\hline Republic of Daghestan & 22.0 & 22.5 & - & - & - \\
\hline State Program & 740.0 & 770.0 & 770.0 & 770.0 & 770.0 \\
\hline Komi Republic & 71.0 & 75.0 & 77.0 & 79.0 & 81.0 \\
\hline State Program & 3090.0 & 3240.0 & 3240.0 & 3240.0 & 3240.0 \\
\hline Primorye Territory & 356.0 & 364.0 & - & - & - \\
\hline State Program & 395.0 & 475.0 & 555.0 & 635.0 & 715.0 \\
\hline Chelaybinsk Region & - & - & - & - & - \\
\hline State Program & 1380.0 & 1420.0 & 1420.0 & 1420.0 & 1420.0 \\
\hline Altai Territory & 1500.0 & 1540.0 & 1540.0 & 1540.0 & 1540.0 \\
\hline State Program & 970.0 & 1020.0 & 1020.0 & 1020.0 & 1020.0 \\
\hline Volgograd Region & 1196 & - & - & - & \\
\hline
\end{tabular}

Source: Authors' own results

We believe that such a discrepancy in strategically important documents is unacceptable and requires mandatory adjustment.

Also noteworthy is the fact that no program document contains provisions on the liability for failure to meet the targets. In recent years, a number of state programs in the Russian Federation have not yielded planned results for reasons related to sanctions imposed on the country. In this regard, we consider it reasonable to supplement the state programs by including the responsibility for failure to meet the target indicators within scheduled timeframes.

To sum it up, it should be noted that the forecasting and planning documents adopted in the Russian Federation lack systematicity. They are not fit for harmonization, contain different values of the same indicator, do not include explanations, economic justification of assumptions and deviations from forecast parameters. This problem is one of the reasons for inefficient budget expenditures, misleads potential executors of program documents, and requires urgent solution.

\section{EMPIRICAL MODEL}

The empirical model presented in this paper focuses on determining the main drivers of innovations in small and medium enterprises. Many related studies (Stephens \& Onofrei, 2012) preoccupied with 
identifying causality as a form of quantitative analysis generally use the econometric model expressed in the following form:

$$
Y=X^{\prime} \beta+\varepsilon
$$

where $Y$ is the measure of enterprise innovations and $X$ is the vector of factors internal to the firm (owner/manager and enterprise characteristics) and factors external to the firm (enterprise strategies). The general econometric model for estimation that was employed in our analysis had the following form:

$$
Y_{i}=\sum_{i=1}^{k} \beta_{k} X_{k i}+\sum_{i=1}^{m} \beta_{m} Z_{m i}+\sum_{i=1}^{l} \beta_{l} W_{l i}+u_{c}+e_{i}
$$

where $\mathrm{X}$ are the exogenous variables of the small model, $\mathrm{Z}$ the extra objective variables of the intermediate model and $\mathrm{W}$ the extra subjective variables added to make the large model. $u_{c}$ is a community identifier.

We used a sample of 15413 SMEs from various Russian regions. The sample was collected using the snowball sampling technique using our own network of interviewers in all main regions of Russia with the state support of SMEs

We employ several econometric techniques in our paper in order to estimate this model. The standard econometric technique employed is the ordinary least squares (OLS) (the issue of heteroscedasticity requires using robust standard errors in all OLS estimations). Moreover, due to the type of the data and the issues that might occur due to unknown location-specifics sometimes the use of generalized least squares is justified. Furthermore, we used Breusch and Pagan test for testing for the presence of individual community effects, Hausman test for individual location effects, and ordinary least square (OLS) estimations with robust standard errors. We test the one-way error model expressed by the fixed effects (FE) model and the random effect (RE) model with the error term with two components: a time-invariant component and a a component that is uncorrelated over time.

Hence, the number of innovations according to categories was selected naturally as explained dependent variable of competitiveness. Dependent variables for the final models were carefully selected when constructing a model capable of identifying the key determinants of innovations.

We run the three models (innovation model, barriers model and state support model) using Stata statistical software package. One has to note that each model has the same list of "basic" variables but differs in the additional binary variables that coded for instance the existence of barriers to business, the structure of ownership, or the impact of the external factors such as competition, or the rule of law ("innovations", "barriers" model, or the "state support" model).

Table 3 above reports the results of all three models in question. The R-squared are quite high (about $70 \%$ ) which makes our model valid. What is also important are the values and the signs of the coefficients, as well as the significance of the coefficients to make predictions of their impact on the innovations in SMEs (dependent variable). Larger markets induce more innovations. This relationship could be also viewed from the other direction meaning that innovation pushes small businesses to expand territorially. Innovations enable the firm to compete internationally and at the same time international market puts more pressure on innovativeness of the offered good.

Licenses did not come through as significant determinant of innovation. This might be explained by their diversity and real impact on firms. This finding supports the argument that patents may not be a good representation of competitiveness and innovations. On the other hand, belonging to the cluster 
plays a positive role. SMEs in the clusters dominated over those that were not aware of the advantages that clusters provide, especially in terms of synergy.

Table 3

Results of empirical model estimations

\begin{tabular}{|c|c|c|c|}
\hline & Innovation model & Barriers model & State support model \\
\hline & RSE & OLS & OLS \\
\hline Small enterprise & $\begin{array}{c}0.1659 * * \\
(0.0596)\end{array}$ & $\begin{array}{c}0.1523 * * \\
(0.061)\end{array}$ & $\begin{array}{c}0.1598 \text { *** } \\
(0.0596)\end{array}$ \\
\hline Medium enterprise & $\begin{array}{l}0.237^{* *} \\
(0.1013)\end{array}$ & $\begin{array}{l}0.230^{* *} \\
(0.1023)\end{array}$ & $\begin{array}{c}0.2459 * * \\
(0.1012)\end{array}$ \\
\hline Turnover & $\begin{array}{c}0.0873^{* * *} \\
(0.0311)\end{array}$ & $\begin{array}{c}0.0838^{* * *} \\
(0.0306)\end{array}$ & $\begin{array}{c}0.0922^{* * *} \\
(0.032)\end{array}$ \\
\hline Cluster & $\begin{array}{l}0.2103^{*} \\
(0.1113) \\
\end{array}$ & $\begin{array}{l}0.2056^{*} \\
(0.1115) \\
\end{array}$ & $\begin{array}{l}0.2085^{*} \\
(0.1127) \\
\end{array}$ \\
\hline Equipment age & $\begin{array}{c}-0.0583^{* *} \\
(0.0282)\end{array}$ & $\begin{array}{c}-0.0597 * * \\
(0.0284)\end{array}$ & $\begin{array}{c}-0.0585^{* *} \\
(0.0285)\end{array}$ \\
\hline Competitors & $\begin{array}{c}0.0417^{* *} \\
(0.017) \\
\end{array}$ & $\begin{array}{c}0.0380^{* *} \\
(0.0173) \\
\end{array}$ & $\begin{array}{l}0.043^{* *} \\
(0.0172) \\
\end{array}$ \\
\hline New technologies & $\begin{array}{c}0.195795^{* * *} \\
(0.0511415)\end{array}$ & $\begin{array}{c}0.2003^{* * *} \\
(0.0519)\end{array}$ & $\begin{array}{c}0.1936^{* * *} \\
(0.051)\end{array}$ \\
\hline Diversification & $\begin{array}{c}.1707^{* *} \\
(0.0711) \\
\end{array}$ & $\begin{array}{c}0.1706^{* *} \\
(0.0715) \\
\end{array}$ & $\begin{array}{c}.1745^{* *} \\
(0.0726) \\
\end{array}$ \\
\hline Quality & $\begin{array}{c}0.2247^{* * *} \\
(0.0484)\end{array}$ & $\begin{array}{c}0.2201^{* * *} \\
(0.0490)\end{array}$ & $\begin{array}{c}0.2211^{* * *} \\
(0.0487)\end{array}$ \\
\hline Market barriers & $\begin{array}{c}-0.1064^{* *} \\
(0.0471) \\
\end{array}$ & $\begin{array}{c}-0.1001^{* *} \\
(0.0481) \\
\end{array}$ & $\begin{array}{c}-0.1007^{* *} \\
(0.0471) \\
\end{array}$ \\
\hline Scientific cooperation & $\begin{array}{c}-0.1402^{* *} \\
(0.0692)\end{array}$ & $\begin{array}{c}-0.150010^{*} \\
(0.0779)\end{array}$ & $\begin{array}{c}-0.1529 * * \\
(0.071)\end{array}$ \\
\hline Financial sources & $\begin{array}{c}0.209^{* * *} \\
(0.082) \\
\end{array}$ & $\begin{array}{c}0.249 * * * \\
(0.081) \\
\end{array}$ & $\begin{array}{c}.213^{* * *} \\
(0.084) \\
\end{array}$ \\
\hline Regulation & $\begin{array}{l}-0.084^{*} \\
(0.081)\end{array}$ & $\begin{array}{c}-0.094 * \\
(0.081)\end{array}$ & $\begin{array}{c}-0.095^{* * *} \\
(0.791)\end{array}$ \\
\hline State support & $\begin{array}{l}0.892^{* *} \\
(0.731)\end{array}$ & $\begin{array}{c}0.921 * * \\
(0.753)\end{array}$ & $\begin{array}{c}0.114 * * * \\
(0.971)\end{array}$ \\
\hline Constant & $\begin{array}{c}2.674 * * * \\
(0.1592)\end{array}$ & $\begin{array}{c}2.671^{* * *} \\
(0.1570)\end{array}$ & $\begin{array}{c}2.657 * * * \\
(0.1629)\end{array}$ \\
\hline Observations & & 15413 & \\
\hline R-squared & 0.67 & 0.66 & 0.66 \\
\hline
\end{tabular}

Note: * 15\% significance, ** 10\% significance, ${ }^{* * *} 5 \%$ significance. RSE stands for „robust standard errors", and OLS stands for "ordinary least squares". The numbers in parentheses are (robust) standard errors.

Source: Authors' own results 
Our results demonstrate that the most significant determinants of rural enterprise's competitiveness are location within a region with competitive situation, enterprise size, enterprise age, and the fact whether enterprise has some form of innovation. Moreover, our findings show that increasing age of equipment is negatively related to competitiveness and innovations. This is quite understandable, as far as the newer equipment allows more innovative usage and implementation. On the contrary, competition had a positive effect (especially higher competition categories). More competitive environment (and probably the state support in the form of the conditions created for the SMEs by the state) forces firms to innovate more.

\section{CONCLUSIONS AND POLICY IMPLICATIONS}

All in all, our analysis of the state support and innovations in SMEs showed the disparity of indicators reflecting the results of their implementation. Some outcomes of the federal program for the small business development are not reflected at all in any of the analyzed programs of the federal subjects.

None of the federal subjects under survey sets the task of the follow-up and support of young entrepreneurs (individuals under the age of 30). In order to eliminate the revealed discrepancies, we propose to supplement the state programs for the small and medium-sized business development implemented in the federal subjects with the tasks of the follow-up and support of young entrepreneurs (individuals under the age of 30). This provision is one of the key conditions enabling the federal subjects to achieve the goals and solve the tasks of the federal subprogram "Development of Small and MediumSized Businesses". Regional programs must be harmonized in the part of clarifying the goals, tasks, target indicators which must necessarily complement each other and in general, contribute to the achievement of the goal of the state target program. The goals and tasks of the regional programs should be consistent in the contents, implementation deadlines and allocated financial resources.

The program documents should include not only the amount of funding for specific activities but also detailed justification of the latter. The key problem of state programs is that they lack justification of both the activities and their funding amounts. In reality there can always be several alternatives to individual task solutions, combinations of resources used and forms of the state support, but "a component that stimulates optimal reallocation of funds falls out" in the current practice of development and implementation of programs. The following data must be justified: priority of the activity and adequate funds for efficient implementation of the activity. Carrying out such a justification is impossible without calculations made on the basis of a particular project (operating or under development). This once again confirms the need to fix the requirements for the activities described in state programs, which, if properly worded, will facilitate the calculation of the necessary financial resources.

Regional SME support programs should be annually updated in respect of funding amounts depending on the achievement of the current year's objectives. The adjustment should be made based on the federal laws and with respect to the provisions of the federal budget. It should be remembered that in 2014-2015 the volumes of financial support for state programs changed many times and did not comply with budget allocations fixed in legislation. In this regard, particular attention should be paid to programs that lack the focus on small-scale perspective of activities with indication of timeframes. It is important to detail the corrective measures for changing target indicators and objectives of government programs depending on the approved scenarios of economic development. There is a need to clarify and detail the goals of state programs and determine the procedures of bringing them in line with the priorities of the economic development, innovations, and socio-economic forecast indicators reflected in the position documents and sectoral strategies. 


\section{REFERENCES}

Abrhám, J., Bilan, Y., Krauchenia, A., \& Strielkowski, W. (2015). Planning horizon in labour supply of Belarusian small entrepreneurs. Economic Research-Ekonomska Istrą̌ivanja, 28(1), 773-787. doi: 10.1080/1331677X.2015.1084238

Barkhatov, V. (2016). Business Success of Small and Medium Sized Enterprises in Russia and Social Responsibility of Managers. Procedia Social and Behavioral Sciences, 221, 185-193. doi: 10.1016/j.sbspro.2016.05.105

Barkhatov, V., Pletnev, D., \& Campa, A. (2016). Key Success Factors and Barriers for Small Businesses: Comparative Analysis. Procedia Social and Behavioral Sciences, 221, 29-38. doi: 10.1016/j.sbspro.2016.05.087

Belas, J., Bilan, Y., Demjan, V., \& Sipko, J. (2015). Entrepreneurship in SME segment: case study from the Czech Republic and Slovakia. Amfiteatru Economic, 17(38), 308-326.

Brodzicki, T. (2016). Does variety matter? Export pattern of Poland prior and after the accession to the EU. International Economics Letters, 4(2), 103-118. doi: 10.24984/iel.2016.4.2.5

Cole, A. (2016). All of us are vulnerable, but some are more vulnerable than others: the political ambiguity of vulnerability studies, an ambivalent critique. Critical Horizons, 17(2), 260-277. doi: 10.1080/14409917.2016.1153896

Chibir, E., \& Shirko T. (2015). Event Tourism in Russian Region: Opportunity for Small-scale Business Growth. Procedia Economics and Finance, 26, 183-187. doi: 10.1016/S2212-5671(15)00916-8

Dai, Na, Ivanov, V., \& Cole, R. A. (2017). Entrepreneurial optimism, credit availability, and cost of financing: Evidence from U.S. small businesses. Journal of Corporate Finance, 44, 289-307. doi: 10.1016/j.jcorpfin.2017.04.005

Dolgih, I.N., Zhdanova A.B., \& Bannova K.A. (2015). The Influence of Taxation on Small Enterprise Development in Russia. Procedia Social and Behavioral Sciences, 166, 216-221. doi: 10.1016/j.sbspro.2014.12.513

Durguner, Sena. (2017). Do borrower-lender relationships still matter for small business loans?. Journal of International Financial Markets, Institutions and Money, 50, 98-118. doi: 10.1016/j.intfin.2017.09.007

Ehrenberger, M., Koudelkova, P., \& Strielkowski, W. (2015). Factors influencing innovation in small and medium enterprises in the Czech Republic. Periodica Polytechnica. Social and Management Sciences, 23(2), 73-83. doi: 10.3311/PPso.7737

Ershova, Nina. (2017). Investment climate in Russia and challenges for foreign business: The case of Japanese companies. Journal of Eurasian Studies, 8(2), 151-160. doi: 10.1016/j.euras.2017.03.001

Fidrmuc, J., \& Gundacker, L. (2017). Income inequality and oligarchs in Russian regions: A note. European Journal of Political Economy, 50, 196-207. doi: 10.1016/j.ejpoleco.2017.09.005

Federal State Statistics Service. (2017). Statistical compendium. Retrieved from http://www.gks.ru/wps/wcm/connect/rosstat main/rosstat/en/main/

Frumina, S.V. (2016). About the state programs stimulating development of small and average business in the Russian Federation. Economics: yesterday, today, tomorrow, 7, 98-107.

Gorevaya, E., \& Khayrullina, M. (2015). Evolution of Business Models: Past and Present Trends. Procedia - Economics and Finance, 27, 344-350. doi: 10.1016/S2212-5671(15)01005-9

Host'ovecký, M., Poláčik, M. (2016). Communication skills as the competitive advantage of sellers. Czech Journal of Social Sciences, Business and Economics, 5(1), 18-26. doi: 10.24984/cjssbe.2016.5.1.2

Iwasaki, I., Maurel, M., \& Meunier, B. (2016). Firm entry and exit during a crisis period: Evidence from Russian regions. Russian Journal of Economics, 2(2), 162-191. doi: 10.1016/j.ruje.2016.06.005

Janda, K., Rausser, G., \& Strielkowski, W. (2013). Determinants of profitability of Polish rural micro-enterprises at the time of EU Accession. Eastern European Countryside, 19, 177-217. doi: 10.2478/eec-2013-0009

Kotane, I., \& Kuzmina-Merlino, I. (2017). Analysis of Small and Medium Sized Enterprises' Business Performance Evaluation Practice at Transportation and Storage Services Sector in Latvia. Procedia Engineering, 178, 182-191. doi: 10.1016/j.proeng.2017.01.093

Koudelková, P., \& Svobodová, P. (2014). Knowledge creation \& sharing as essential determinants of SMEs innovation. International Economics Letters, 3(1), 12-20. doi: 10.24984/iel.2014.3.1.3 
Kozubikova, L., Belas, J., Bilan, Y., \& Bartos, P. (2015). Personal Characteristics of Entrepreneurs in the Context of Perception and Management of Business Risk in the SME Segment. Economics \& Sociology, 8(1), 41-54. doi: 10.14254/2071- 789X.2015/8-1/4

Kuhn, Kristine M., Galloway, Tera L., \& Collins-Williams, Maureen. (2017). Simply the best: An exploration of advice that small business owners value. Journal of Business Venturing Insight, 8, 33-40. doi: 10.1016/j.jbvi.2017.05.003

Machová R., Huszárik E.S., \& Šimonová M. (2016). Selected aspects of innovation policy for small and medium sized enterprises, Journal of International Studies, 9(2), 219-232.

Melnichuk, M.V. (2017). Foreign experience of regulation of small business development and its application in Russian reality. Problems of economics and legal practice, 2, 18-21.

Nikolaeva E., \& Pletnev, D. (2016). The Role of the Transaction Costs in the Business Success of Small and Medium Sized Enterprises in Russia. Procedia Social and Behavioral Sciences, 221, 176-184. doi: 10.1016/j.sbspro.2016.05.104

Niño-Amézquita, J., Dubrovsky. V., \& Jankurová, A. (2017). Innovations and competitiveness in regional development: a comparison of Latin America, Europe, and China. Czech Journal of Social Sciences, Business and Economics, 6(1), 28-36. doi: 10.24984/cjssbe.2017.6.1.4

Novikov, Igor. (2014). How does Institutional Environment Affect the Internationalization of Small Enterprises?. Procedia - Economics and Finance, 12, 489-497. doi: 10.1016/S2212-5671(14)00371-2

Paiho, S., Abdurafikov, R., Hoang, Ha, \& Kuusisto, J. (2015). An analysis of different business models for energy efficient renovation of residential districts in Russian cold regions. Sustainable Cities and Society, 14, 31-42. doi: 10.1016/j.scs.2014.07.008

Plotnikov, V., \& Leontyev, E. (2015). Efficiency of Small Business Management in the Communications Industry: Simulation of the Competitive Environment. Procedia Economics and Finance, 27, 177-185. doi: 10.1016/S22125671(15)00987-9

Proskurina, S., Heinimö, J., Mikkilä, M., \& Vakkilainen, E. (2015). The wood pellet business in Russia with the role of North-West Russian regions: Present trends and future challenges. Renewable and Sustainable Energy Reviews, 51, 730-740. doi: 10.1016/j.rser.2015.06.051

Sadykov, M.A. (2017). Special tax regimes in 2017. Tax Policy and Practice, 8(176), 42-45.

Simionescu, M., Bilan, Y., Smrcka, L., \& Vincurova, Z. (2017). The Effects of European Economic Integration and the Impact of Brexit on the UK Immigrants from the CEE Countries. E \& M Ekonomie a Management, 20(1), 29-47. doi:10.15240/tul/001/2017-1-003

Shaykheeva, D.K. (2015). Analysis of SMEs in Medium-sized Cities' Influence Zone in Tatarstan. Procedia Economics and Finance, 24, 620-624. doi: 10.1016/S2212-5671(15)00650-4

Stephens, S., \& Onofrei, G. (2012). Measuring business incubation outcomes: an Irish case study. The International Journal of Entrepreneurship and Innovation, 13(4), 277-285. doi: 10.5367/ijei.2012.0094

Strielkowski, W., \& Höschle, F. (2016). Evidence for economic convergence in the EU: The analysis of past EU enlargements. Technological and Economic Development of Economy, 22(4), 617-630. doi:10.3846/20294913.2014.890138

Strielkowski, W., Tcukanova, O., \& Zarubina, Z. (2017). Globalization and economic integration: the role of modern management. Polish Journal of Management Studies, 15(1), 255-281. doi: 10.17512/pjms.2017.15.1.24

Varanavicius, V., Navikaite, A., Bilan, Y., \& Strielkowski, W. (2017). Analysis of Consumer Behaviour in Regional Energy Consumption. Economy of Region, 13(1), 147-156. doi: 10.17059/2017-1-14

Viesi, D., Pozzar F., Federici A., Crema, L., \& Mahbub, Md S. (2017). Energy efficiency and sustainability assessment of about 500 small and medium-sized enterprises in Central Europe region. Energy Policy, 105, 363-374. doi:10.1016/j.enpol.2017.02.045

Yakovlev, A. (2016). What is Russia trying to defend?. Russian Journal of Economics, 2(2), 146-161. 